\title{
MODERN COMMUNICATION AND RELATIONSHIPS AS SOURCES OF HAPPINESS
}

In Happiness And Contemporary Society : Conference Proceedings Volume (Lviv, March, 20-21, 2021). Lviv: SPOLOM, 2021. P. 35-37. https://doi.org/10.31108/7.2021.4

ISBN 978-966-919-697-2

БАЗИЛЕВИЧ Андрій

\section{СПІЛКУВАННЯ ТА СТОСУНКИ - ДЖЕРЕЛА ЩАСТЯ}

// Щастя та сучасне суспільство : збірник матеріалів міжнародної наукової конференції (Львів, 20-21 березня 2021 р.). - Львів : СПОЛОМ, 2021. С. 35-37. https://doi.org/10.31108/7.2021.4

ISBN 978-966-919-697-2 


\author{
BAZYLEVYCH Andriy \\ Doctor of Medical Sciences, Professor, \\ President of World Federation of Ukrainian Medical Associations \\ Department of Propedeutics of Internal Medicine №1, \\ Danylo Halytsky National Medical University \\ The Ukrainina Institute for Happiness Research (Lviv, Ukraine)
}

\title{
COMMUNICATION AND RELATIONSHIPS AS SOURCES OF HAPPINESS
}

Among the seven "Ss" in the Ukrainian language - Sweets, Sports, Sleep, Sex, Smile, Communication and Relationships - the last two components are perhaps the most important. Communication shapes the human essence. The modern features of human communication, associated with the era of digitalization, when gadgets replace natural human communication are especially interesting. According to a study by Columbia University led by Maya Rossignac-Milon, the common reality is seen as a "third partner" in any relationship.

The pinnacle of a relationship is a good family. Healthy relationships in the family are characterized by communication and the desire to maintain a high level of respect and trust. Every personality is a builder of their Happiness and therefore has the right to choose what they want in their life! Communicate, build relationships and stay well!

Key words: communication, relationships, sources of happiness, digitalization, common reality.

\author{
БАЗИЛЕВИЧ Андрій \\ доктор медичних наук, професор \\ президент Світової Федераиії Українських лікарських товариств, \\ кафедра пропедевтики внутрішньої медицини №1, \\ Львівський національний медичний університет імені Данила Галицького \\ Украйнський інститут дослідження щастя (Львів, Украӥна)
}

\section{СПІЛКУВАННЯ ТА СТОСУНКИ - ДЖЕРЕЛА ЩАСТЯ}

Серед 7 «С»: Солодке, Спорт, Сон, Секс, Сміх, Спілкування та Стосунки останні дві складові чи не найважливіші. Спілкування формує людську сутність. Цікавими є сучасні особливості в спілкуванні пов'язані з ерою діджеталізації, коли гаджетами замінюють природнє людське спілкування. Дані дослідження Колумбійського університету під керівництвом Майї Россіньяк-Мілон розглядає спільну реальність, як «третього партнера» у будь-яких стосунках. Вершиною відносин виступає гарна Сім'я. Здорові стосунки в родині характеризуються спілкуванням та прагненням підтримувати високий рівень поваги та довіри. Кожна особистість є будівничою свого Щастя і тому має право вибирати те, що бажає в своєму житті! Спілкуйтеся та створюйте стосунки на Здоров’я! 
Ключові слова: спілкування, стосунки, джерела щастя, діджитилізація, спільна дійсність.

Що лежить у формуванні відчуття Щастя?

До відомих 5 «С»: Солодке, Спорт, Сон, Секс, Сміх ще додамо, напевно найважливіші дві складові - Спілкування, Стосунки [1].

Серед всіх цих механізмів та впливів на відчуття щастя саме СПІЛКУВАННЯ напевно є найбільшим соціальною складовою.

Спілкування, в одному з визначень - це процес встановлення і розвитку контактів між людьми, який породжується потребами спільної діяльності і містить обмін інформацією, вироблення єдиної стратегії взаємодії, сприйняття та розуміння іншої людини. [2]

Також згідно відомої теорії цінностей Маслоу після біологічної складової (забезпечення фізіологічних потреб і особистої безпеки), на другому рівні $\epsilon$ соціальна складова (спілкування та місце в суспільстві).

Спілкування формує людську сутність. Саме через спілкування людина реалізує себе, як особистість, утверджує, досягає своїх цілей. Так відомий філософ Григорій Сковорода стверджував, що саме спілкуючись, кожна людина реалізує свої природні можливості. I щастя можна реалізувати тільки через навчання та самопізнання. Тоді як корінь нещастя в неправильному розумінні своїх здібностей, самого себе.

Деколи глибина спілкування 3 давніми друзями 3 часом послаблюються та життєві шляхи з друзями розходяться. Необхідно не тільки вберегти в пам'яті гарні моменти - варта деколи зустрітися, чи хоча б вітати 3 днями народженнями. Можливо підтримання взаємних стосунків дасть можливість комусь принести радість. А деколи дружня, цінна порада зможе і вивести 3 «кризової» ситуації чи навіть врятувати.

Важливим в стосунках - вміння пробачати, навіть якщо виникла образа чи навіть ненависть. Тому що, образи часто заставляють тримати в душі негатив, не дають нам 3 легкістю йти вперед, жити повним життям і ставати кращими. Це тягне особистість назад, примушуючи постійно озиратися і перейматися життям своїх «конкурентів». Тому навчитися пробачати та з розумінням ставитися до «кривдників» дозволить жити своїм сьогоденням та гарним майбутнім.

Цікавими є сучасні особливості в спілкуванні. В еру діджеталізації діти, молодь та деколи дорослі гаджетами замінюють природнє людське спілкування. Втрачається невербальна комунікація за допомогою немовних засобів - міміки, пауз, манер, жестів. Сприйняття текстових меседжів часом перекручують зміст та приводять навіть до конфліктів. "Мова почуттів" - погляди, дотики, емоції втрачається. А деколи зустрівшись, замість розмови 3 другом, витягаються смартфони і починається прокручування стрічки соціальних мереж чи віртуальні гри. I частка «живих» комунікацій зводиться до мінімуму.

Вищою формою спілкування $є$ формуванням тривалих СТОСУНКІВ.

Саме спілкування, наші розмови, будь то 3 новим знайомим, старим товаришем чи в родині, стосуються навколишнього світу, а не нас самих. Такі розмовами наближають нас один до одного. Психолог Колумбійського університету Майя Россіньяк-Мілон називає це "осмисленням світу разом". Навіть 
розглядає таку спільну реальність, як «третього партнера» у будь-яких стосунках. I вважає, що це секретом добрих стосунків. [3]

Разом зі своїми співдослідниками, Россіньяк-Мілон розробила опитувальник, який вимірюв ступінь переживання пар спільною реальністю. Дослідник просить кожного партнера оцінити свою згоду чи незгоду з такими твердженнями, як: "Ми часто думаємо про речі в один і той же час" або "Завдяки дискусіям ми часто досягаємо спільної точки зору". Використовуючи цей метод, Цим доведено, що люди, які відчувають більше спільної реальності зі своїм партнером, також почуваються більш відданими одне одному. Дійсно, у дні, коли пари відчувають більше цього когнітивного злиття, вони також почуваються емоційно ближчими. У довготривалих стосунках показує це дослідження, що відчуття спільної реальності може стати схожим на єдину лінзу, через яку партнери фільтрують навколишній світ; розуми зустрічаються, синхронізуються та зливаються.

Сімейні стосунки посідає важливе місце в житті кожної людини. Вона покликана забезпечувати захист та сприятливі умови для всіх членів сім'ї.

Вершиною відносин виступає гарна СІМ'Я. Здорові стосунки в родині характеризуються спілкуванням та прагненням підтримувати високий рівень поваги та довіри. Вони характеризуються взаємним піклуванням і підтримкою. Батьківська турботою розвиває у дітей відповідні цінності та впевненість у собі. 3 віком та тривалістю стосунки роблять у сім'ї неймовірні речі, дозволяють створювати міцні та щасливі родини.

Отже, зізнавайтесь своїм близьким в любові, коханні. Частіше говоріть своїм рідним та близьким про свої почуття, про те що ви їх дуже любите. Даруйте імм подарунки, дивуйте, створюйте радісні моменти - навіть маленькими дрібничками, проте від щирого серця! Адже час, проведений разом з улюбленими є найкращим подарунок і для того кому приділена увага і тому хто дарує.

Серед багатьох мірил чи мрій про ЩАСТЯ можна зустріти матеріальне багатство (гарний будинок, модний автомобіль), кар'єрна мета в житті, бажання домінувати над іншими, то в багатьох таки стає кохана людина поруч.

Кожна особистість є будівничою свого Щастя і тому має право вибирати те, що бажає в своєму житті!

Спілкуйтеся та створюйте стосунки на ЗДОРОВ’Я!

\section{ЛІТЕРАТУРА}

1. Базилевич А. Як можна підвищити рівень «гормонів щастя»? / Щастя та сучасне суспільство : збірник матеріалів міжнародної наукової конференції (Львів, 2021 березня 2020 р.). - Львів : СПОЛОМ, 2020. - С. 30-33.

2. Кайдалова Л.Г. Психологія спілкування: навчальний посібник. / Кайдалова Л.Г., Пляка Л.В. / Х. : НФаУ, 2011. 132 с.

3. https://ukrclassic.com.ua/katalog/s/skovoroda-grigorij/501-grigorij-skovorodarozmova-p-yati-podorozhnikh-pro-istinne-shchastya-u-zhitti?showall=1

4. Rossignac-Milon, M. / Merged minds: Generalized shared reality in dyadic relationships. / Rossignac-Milon, M., Bolger, N., Zee, K. S., Boothby, E. J., \& Higgins, E. T. // Journal of Personality and Social Psychology. Jul 1, 2020 